\title{
PENGARUH DESAIN BANGUNAN PARAMOUNT SKYLINE COMPLEX TERHADAP AKSESIBILITAS DRIVER ONLINE KE UNIVERSITAS MATANA
}

\author{
Zenon Hassel ${ }^{1}$, Moses Luca² \\ Program Studi Arsitektur, FSTEM, Universitas Matana ${ }^{1,2}$
}

\begin{abstract}
Abstrak
Pertumbuhan penduduk di indonesia membuat jumlah kendraan bermotor bertambah dengan pesat membuat orang semakin malas menggunkan angkutan umum. Akan tetatapi ada beberapa orang membuat aplikasi angkutan umum online seperti ojek online dan taksi online. Dengan adanya aplikasi itu orang semakin mau mengunakan aplikasi tersebut untuk meningkatkan orang untuk menggunakan angkutan umum tersebut. Banyak yang mengunakan aplikasi tersbut adalah pekerja kantoran dan mahasiswa. Untuk bangunan paramount skyline complex disini membuat aksesbilitas untuk area pejemputan untuk driver online. Untuk menentukan sirkulasi di area universitas matana. Penelitian ini menggunakan metode kuantitatif untuk mengetahui bahwa ada atau tidaknya pengaruh tersebut dengan menggunakan software SPSS versi 16. Melalui penelitian ini diharapkan dapat memberi pengetahuan mengenai pengaruh desain bangunan paramount skyline complex terhadap aksebilitas driver online ke universitas matana. Hasil penelitian ini menunjukkan bahwa ternyata memang ada hubungan yang kuat dan signifikan dengan $r=0,776$ dan $t=8,520$ antara setting peron terhadap adaptabilitas pengguna KRL. Dan pengaruh setting peron terhadap adaptabilitas pengguna KRL sebesar $60,2 \%$.
\end{abstract}

Kata Kunci : Arsitektur Perilaku, Sirkulasi, Aksebilitas.

\begin{abstract}
Population growth in Indonesia makes the number of motorized vehicles increase rapidly making people increasingly lazy to use public transportation. But there are some people making online public transport applications such as online motorcycle taxi and online taxis. With the application, people are increasingly willing to use the application to increase people to use public transportation. Many who use the application are office workers and students. For paramount skyline complex buildings here make accessibility for the pickup area for online drivers. To determine circulation in the area of the Matana University. This study uses a quantitative method to determine that the presence or absence of these influences using SPSS version 16. Through this study, it is expected to provide knowledge about the influence of the paramount skyline complex building design on the accessibility of online drivers to matana universities. The results of this study indicate that in fact there is a strong and significant relationship with $r=0.776$ and $t=8.520$ between platform settings for the adaptability of KRL users. And the influence of platform settings on the adaptability of KRL users is $60.2 \%$.
\end{abstract}




\section{Pendahuluan}

Salah satu area yang ada di bangunan paramount skyline complex terdapat bangunan universitas. Universitas adalah Kampus adalah suatu tempat yang digunakan mahasiswa untuk menempuh jenjang pendidikan tinggi. Pendidikan tinggi merupakan jenjang pendidikan setelah pendidikan menengah yang mencakup program pendidikan diploma, sarjana, magister, spesialis, dan doktor yang diselenggarakan oleh pendidikan tinggi. Hubungan kelompokan bangunan universitas dilengkapi dengan:

Pola sirkulasi area aksesbilitas untuk area jemput penumpang. Aksesibilitas adalah suatu ukuran kenyamanan atau kemudahan mengenai cara lokasi tataguna lahan berintekasi satu dengan yang lain dan bagaimana "Mudah" atau "Susah"nya lokasi tersebut dicapai melalui sistem jaringan transportasi. Persyaratan teknis fasilitas dan aksesibilitas pada bangunan gedung dan lingkungan meliputi:

1. Keselamatan, yaitu setiap bangunan yang bersifat umum dalam suatu lingkungan terbangun, harus memperhatikan keselamatan bagi semua orang.

2. Kemudahan, yaitu setiap orang dapat mencapai semua tempat atau bangunan yang bersifat umum dalam suatu lingkungan.

3. Kegunaan, yaitu setiap orang harus dapat mempergunakan semua tempat atau bangunan yang bersifat umum dalam suatu lingkungan.

4. Kemandirian, yaitu setiap orang harus bisa mencapai, masuk dan mempergunakan semua tempat atau bangunan yang bersifat umum dalam suatu lingkungan dengan tanpa membutuhkan bantuan orang lain.

\section{Metode Penelitian}

Untuk mendapatkan ada atau tidak adanya pengaruh, maka digunakan metode kuantitatif. Pengumpulan data diadakan dengan kuesioner terhadap 50 responden yang berada pada area bangunan universitas matana pada saat jam sibuk di pagi dan sore hari. Skala yang digunakan pada kuesioner.

Data lalu diproses dengan software SPSS versi 16 , dengan menguji validitas dan reliabilitas data dan menguji hipotesis yang meliputi uji korelasi, uji signifikansi, koefisien determinasi dan uji regresi sederhana (Sugiyono, 2007). Berikut hipotesis sementara: Ho : $\rho=0$ - tidak terdapat penaruh yang signifikan antara desain bangunan paramount skyline complex terhadap aksebilitas driver online ke universitas matana. Ha : $\rho \neq 0$ - terdapat pengaruh yang signifikan antara desain bangunan paramount skyline complex terhadap aksebilitas driver online ke universitas matana. 
PENGARUH DESAIN BANGUNAN PARAMOUNT SKYLINE COMPLEX TERHADAP AKSESIBILITAS DRIVER ONLINE KE UNIVERSITAS MATANA

\begin{tabular}{|l|l|}
\hline Indikator & Sub Indikator \\
\hline A. Fungsi & a. Bangunan universitas \\
\hline & b. Desain bangunan \\
\hline B. Bentuk & a. Lokasi \\
\hline & b. Konfigurasi desain \\
\cline { 2 - 2 } & C. Kenyamanan \\
\hline C. Dimensi & a. Luasan jalan \\
\hline & b. Luasan bangunan \\
\hline
\end{tabular}

Tabel 1. Variabel X: Desain Bangunan Paramount Skyline Complex (Sumber: Observasi Lapangan, 2018)

\begin{tabular}{|l|l|}
\hline Indikator & Sub Indikator \\
\hline A. Pengguna & a. Prefrensi pumpang \\
\hline & b. Prefrensi driver \\
\hline B. Sirkulasi & $\begin{array}{l}\text { a. Tata Letak dan pola } \\
\text { sirkulasi }\end{array}$ \\
\hline C. Aktivitas & a. Mengambil order \\
\hline & b. Akses masuk bangunan \\
\hline
\end{tabular}

Tabel 2. Variabel Y: Aksebilitas Driver Online Ke Universitas Matana (Sumber: Observasi Lapangan, 2018)

\section{Hasil dan Pembahasan}

Pada Gambar 3. Dapat dilihat dari 50 orang sample terdiriantara driver online di wilayah universitas matana sebagai responden maka presentasi responden terbayak oleh driver online.

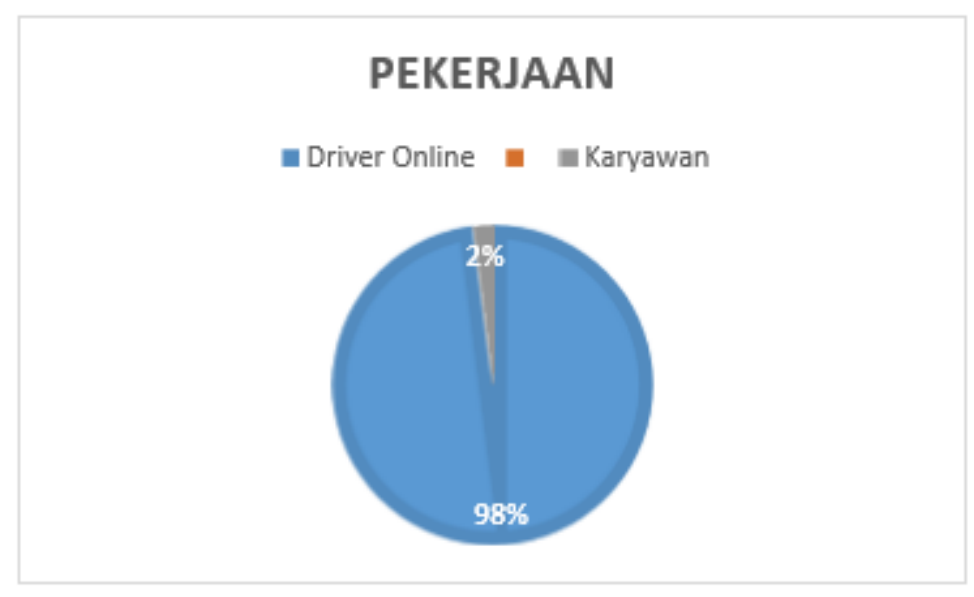

Gambar 1. Diagram Pekerjaan

Pada Gambar 2. Dapat dilihat bahwa dari 50 orang samper terdiri antara Driver online yang terdapat di wilayah Universitas Matana sebagai responden, maka presentase responden terbanyak berada di antara umur $23-27$ tahun yakni sebanyak 52\% lalu umur $18-22$ tahun sebanyak $18 \%$, dan umur 28 - 32 sebanyak $30 \%$. 


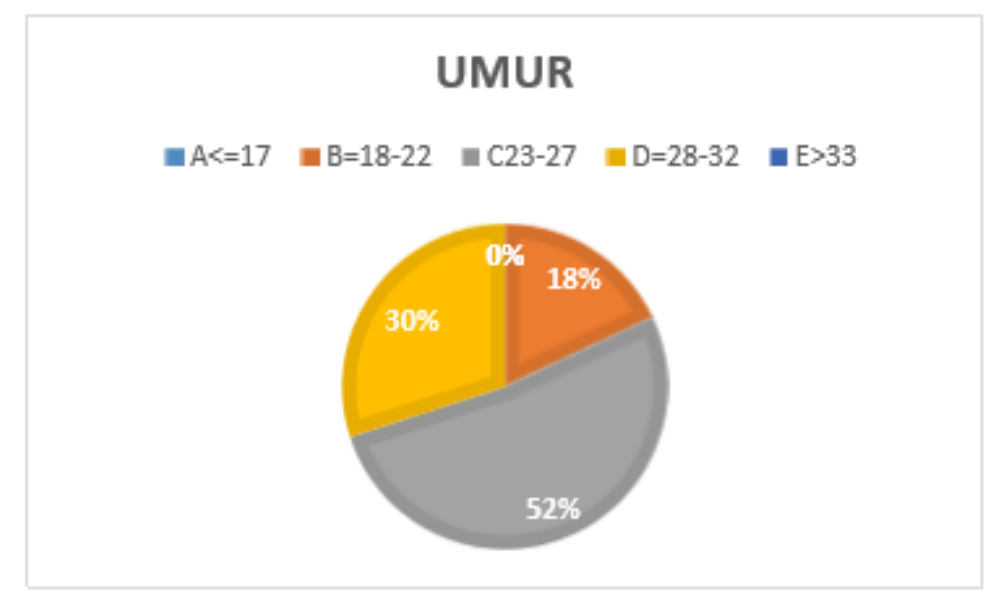

Gambar 2. Diagram Pekerjaan

Pada Gambar 3. Dapat dilihat bahwa dari 50 orang sampel terpilih dari driver online yang berada dikawasan Universitas Matana sebagai responden 50 orang laki -laki.

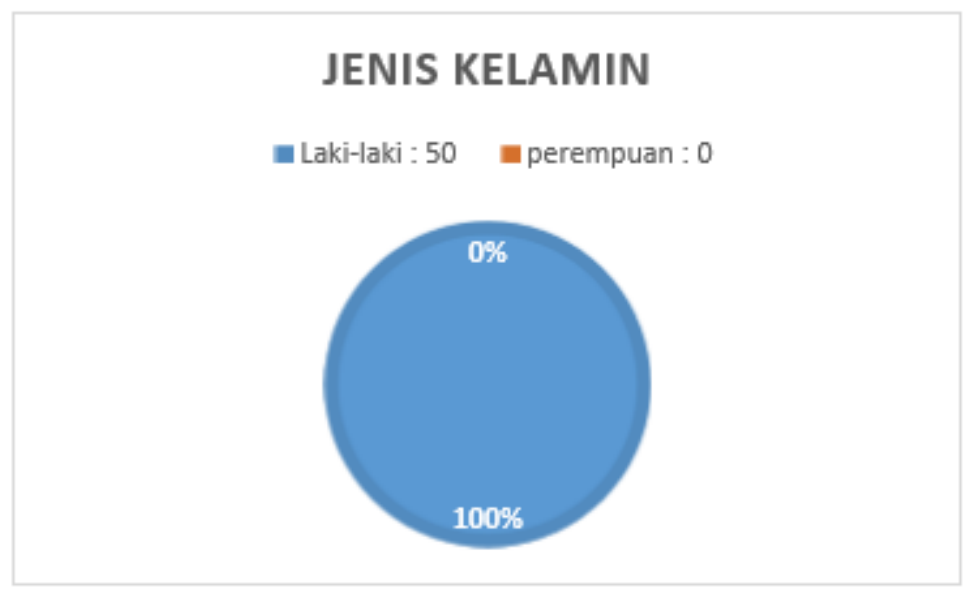

Gambar 3. Diagram Jenis Kelamin

Pada Gambar 7. Pada pernyataan variabel x (Desain Universitas) pernyataan ke -1 terlihat bahwa responden terbanyak yaitu memilih sangat setuju dan yang paling sedikit adalah sangat tidak setuju. Pada pernyataan variabel $x$ (Desain Universitas) pernyataan ke -2 terlihat bahwa responden terbanyak yaitu memilih setuju dan yang paling sedikit adalah sangat tidak setuju. Pada pernyataan variabel $x$ (Desain Universitas) pernyataan ke -3 terlihat bahwa responden terbanyak yaitu memilih setuju dan yang paling sedikit adalah sangat tidak setuju. Pada pernyataan variabel $\times$ (Desain Universitas) pernyataan ke -4 terlihat bahwa responden terbanyak yaitu memilih setuju dan yang paling sedikit adalah sangat tidak setuju. Pada pernyataan variabel $x$ (Desain Universitas) pernyataan ke -5 terlihat bahwa responden terbanyak yaitu memilih setuju dan yang paling sedikit adalah sangat tidak setuju. Pada pernyataan variabel x (Desain Universitas) pernyataan ke -6 terlihat bahwa responden terbanyak yaitu memilih setuju dan yang paling sedikit adalah sangat tidak setuju. Pada pernyataan variabel $x$ (Desain Universitas) pernyataan ke -7 terlihat bahwa responden terbanyak yaitu memilih setuju dan yang paling sedikit adalah sangat tidak setuju. 


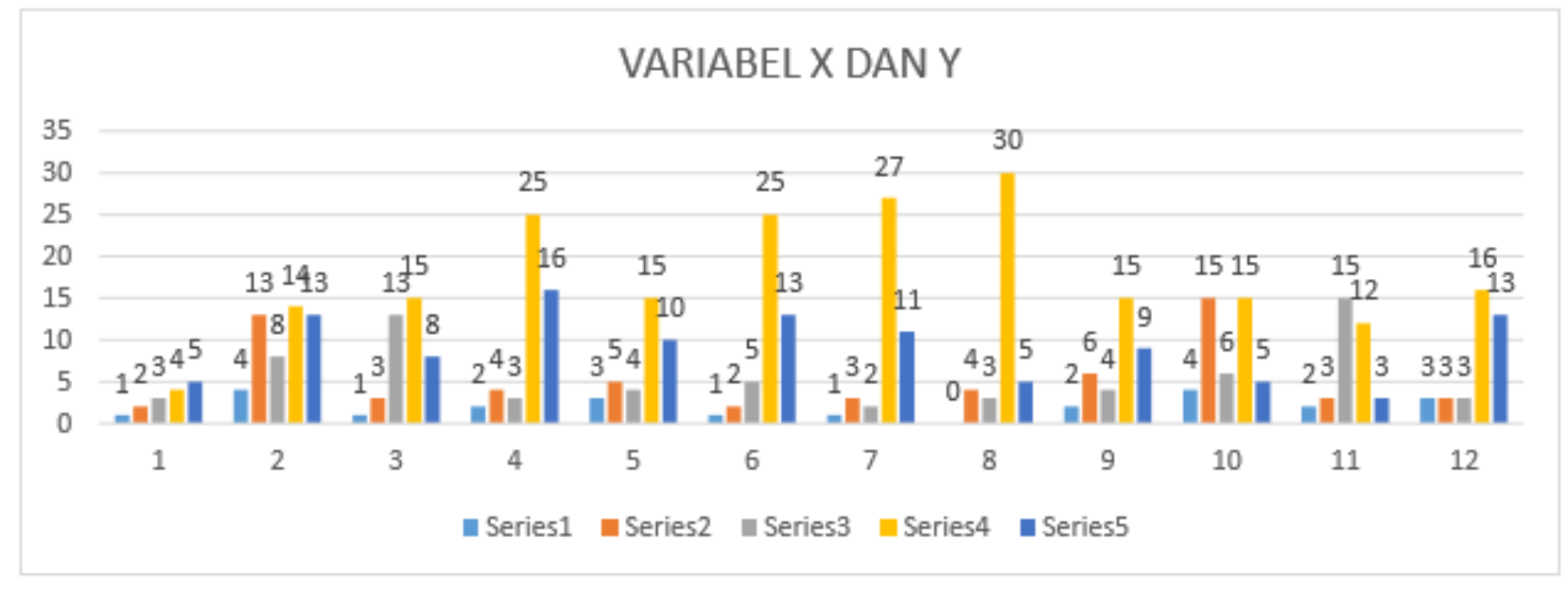

Gambar 3. Diagram Data Variabel X dan Y

Pada Gambar 3. Pada pernyataan variabel y (Aksesibilitas) pernyataan ke -8 terlihat bahwa responden terbanyak yaitu memilih setuju dan yang paling sedikit adalah sangat tidak setuju. Pada pernyataan variabel y (Aksesibilitas) pernyataan ke -9 terlihat bahwa responden terbanyak yaitu memilih setuju dan yang paling sedikit adalah sangat tidak setuju. Pada pernyataan variabel y (Aksesibilitas) pernyataan ke -10 terlihat bahwa responden terbanyak yaitu memilih setuju dan tidak setuju lalu yang paling sedikit adalah sangat tidak setuju. Pada pernyataan variabel y (Aksesibilitas) pernyataan ke -11 terlihat bahwa responden terbanyak yaitu memilih ragu-ragu dan yang paling sedikit adalah sangat tidak setuju. Pada pernyataan variabel y (Aksesibilitas) pernyataan ke -12 terlihat bahwa responden terbanyak yaitu memilih setuju dan yang paling sedikit terdapat : sangat tidak setuju,tidak setuju, dan ragu-ragu.

\section{Uji Validitas}

Uji Validitas yang di lakukan menggunakan korelasi pearson dalam software SPSS Uji Validasi ini bertujuan untuk mengetahui apakah setiap pernyataan yang diberikan dalam kuesioner sudag valid untuk mengukur variable-variabel yang diteliti. Dari uji validitas didapatkan hasil sebagai berikut.

\begin{tabular}{|l|l|l|l|}
\hline ITEM PERTAYAAN & HITUNG & R TABLE & KETERANGAN \\
\hline P1 & 0,818 & 0,238 & VAILD \\
\hline P2 & 0,780 & 0,238 & VAILD \\
\hline P3 & 0,813 & 0,238 & VAILD \\
\hline P4 & 0,812 & 0,238 & VAILD \\
\hline P5 & 0,812 & 0,238 & VAILD \\
\hline P6 & 0,652 & 0,238 & VAILD \\
\hline P7 & 0,571 & 0,238 & VAILD \\
\hline XTOTAL & 1 & 0,238 & VALID \\
\hline
\end{tabular}

Tabel 3. Hasil Uji Validitas Pernyataan Variabel [X] (Sumber: Analisa, 2018) 
Zenon Hassel dan Moses Luca

\begin{tabular}{|l|l|l|l|}
\hline ITEM PERTAYAAN & HITUNG & R TABLE & KETERANGAN \\
\hline P8 & 0,731 & 0,238 & VAILD \\
\hline P9 & 0,598 & 0,238 & VAILD \\
\hline P10 & 0,683 & 0,238 & VAILD \\
\hline P11 & 0,841 & 0,238 & VAILD \\
\hline P12 & 0,697 & 0,238 & VAILD \\
\hline YTOTLA & 1 & 0,238 & VALID \\
\hline
\end{tabular}

Tabel 4. Hasil Uji Validitas Pernyataan Variabel [Y] (Sumber: Analisa, 2018)

Dari hasil di atas, bahwa pernyataan-pernyataan pada variabel $\mathrm{X}$ dan $\mathrm{Y}$ tersebut adalah valid, karena lebih besar dari $r$ tabel $=0,238$. Sehingga data kuesioner dapat digunakan untuk uji hipotesis.

\section{Uji Reliabilitas}

Pengukuran reliabilitas yang dilakukan menggunakan rumus Cronbach Alpha dalam software SPSS. Uji reliabilitas ini menyertakan seluruh komponen pernyataan pada setiap variable yang 'valid' dan mengabaikan komponen pernyataan yang 'tidak valid', Dari suatu variabel dikatakan reliable jika nilai alphanya lebih dari 0,30 .

\begin{tabular}{|l|l|}
\hline \multicolumn{2}{|l|}{ Reliability Statistics } \\
\hline Cronbach's Alpha & N of Items \\
\hline 0.873 & 7 \\
\hline
\end{tabular}

Tabel 5. Hasil Uji Reliabilitas Pernyataan Variabel [X] (Sumber: Analisa, 2018)

\begin{tabular}{|l|l|}
\hline \multicolumn{2}{|l|}{ Reliability Statistics } \\
\hline Cronbach's Alpha & N of Items \\
\hline 0.755 & 5 \\
\hline
\end{tabular}

Tabel 6. Hasil Uji Reliabilitas Pernyataan Variabel [Y] (Sumber: Analisa, 2018)

Dari hasil di atas, bahwa pernyataan-pernyataan pada variabel $X$ dan $Y$ tersebut adalah reliable, karena lebih besar dari $\alpha=0,3$. Sehingga data kuesioner dapat digunakan untuk uji hipotesis.

\section{Uji Korelasi}

Uji korelasi dilakukan dengan metode koefisien korelasi dengan bantuan software SPSS versi 16. Dari hasil perhitungan dapat diketahui bahwa terdapat hubungan yang positif sebesar 0,776 antara desain bangunan paramount skyline complex terhadap aksesbilitas driver online ke universitas matana. Untuk dapat memberikan interpretasi terhadap kuatnya hubungan maka dapat digunakan pedoman seperti yang tertera pada tabel berikut ini. 


\begin{tabular}{|c|c|c|c|}
\hline \multicolumn{4}{|c|}{ Correlations } \\
\hline & & variableX & variableY \\
\hline \multirow[t]{3}{*}{ variableX } & Pearson Correlation & 1 & $.776^{\prime \prime}$ \\
\hline & Sig. (2-tailed) & & .000 \\
\hline & $\mathrm{N}$ & 50 & 50 \\
\hline \multirow[t]{3}{*}{ variableY } & Pearson Correlation & $.776^{\prime \prime}$ & 1 \\
\hline & Sig. (2-tailed) & .000 & \\
\hline & $\mathrm{N}$ & 50 & 50 \\
\hline
\end{tabular}

Tabel 7. Hasil Uji Korelasi (Sumber: Analisa, 2018)

Berdasarkan hasil perhitungan di atas maka terlihat bahwa koefisien korelasi yang ditemukan sebesar 0,776. koefisien korelasi sebesar 0,776 termasuk pada kategori kuat. Jadi, didapat hubungan yang kuat antara variabel $x$ (desain bangunan paramount skyline complex) dan variabel y (aksebilitas driver online ke universitas matana).

\begin{tabular}{|c|c|} 
Interval Koefisien & Tingkat Hubungan \\
\hline $0,00-0,199$ & Sangat rendah \\
\hline $0,20-0,399$ & Rendah \\
\hline $0,40-0,599$ & Sedang \\
\hline $0,60-0,799$ & Kuat \\
\hline $0,80-1,000$ & Sangat kuat \\
\hline
\end{tabular}

Tabel 8. Pedoman Interpretasi Koefisien Korelasi (Sumber: Sujarweni dan Endrayanto, 2012)

\section{Koefisien Determinasi}

Untuk mengetahui seberapa besar variabel $x$ (desain bangunan paramount skyline complex) mempengaruhi variabel y (aksebilitas driver online ke universitas matana) maka kemudian dicari koefisien determinasinya (koefisien penentu) yaitu dengan menggunakan rumus sebagai berikut: $K d=r 2 \times 100 \% \mathrm{Kd}=0,602176 \times 100 \% \mathrm{Kd}=60,2 \%$ Dari hasil perhitungan koefisien determinasi di atas maka dapat diketahui bahwa keberpengaruhan antara desain bangunan paramount skyline complex terhadap aksebilitas driver online ke universitas matana sebesar 60,2 \% dan sisanya sebesar $39,8 \%$ dipengaruhi oleh faktor lain seperti alasan posisi menunggu, keamanan, dan sebagainya.

\section{Uji Signifikansi}

Untuk menguji signifikansi korelasi, yaitu apakah hubungan yang ditemukan itu berlaku untuk seluruh sampel yang berjumlah 50 orang, maka perlu diuji signifikansinya. Adapun rumus uji signifikansi product moment. $\mathrm{t}$ tabel dengan tingkat signifikansinya sebesar $5 \%$ atau $=0,05 \mathrm{dk}=\mathrm{n}$ 2. Untuk mencari nilai t table ditentukan dengan $\mathrm{dk}=\mathrm{n}-2 ;=0,05$, dengan demikian $\mathrm{dk}=50-2=$ $48 ;=0,05$ maka dari perhitungan tersebut didapatkan nilai dk $50 ;=0,05$ sebesar 1,677 (Sujarweni dan Endrayanto, 2012). Hasil perhitungan t hitung sebesar 8,520 dan nilai t table sebesar 1,677. Dengan demikian $t$ hitung $\geq \mathrm{t}$ table, maka Ha diterima dan Ho ditolak, artinya terdapat hubungan 
yang signifikan antara desain bangunan paramount skyline complex terhadap aksebilitas driver online ke universitas matana, seperti pada gambar kurva di bawah ini.

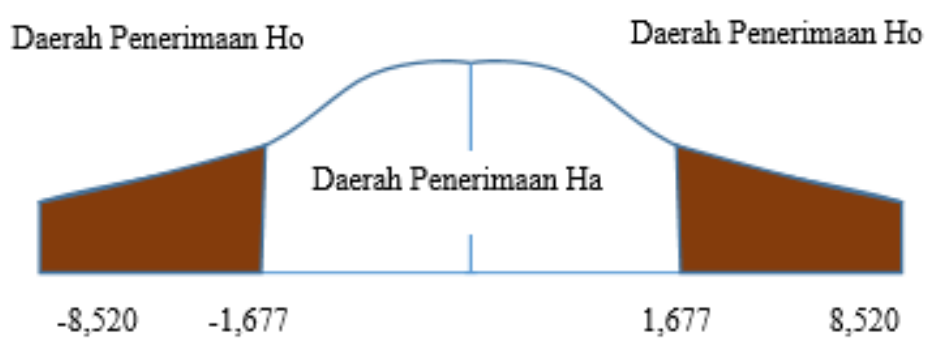

Gambar 4. Kurva Signifikansi Korelasi

\section{Persamaan Regresi}

Selanjutnya untuk menguji seberapa hubungan desain bangunan paramount skyline complex terhadap aksebilitas driver online ke universitas matana, maka dilakukan perhitungan dengan analisa regresi linier sederhana.

Berdasarkan perhitungan di atas telah ditemukan $a=6,656$ dan $b=1,106$ Dengan demikian bentuk pengaruh antara variabel desain bangunan paramount skyline complex terhadap aksebilitas driver online ke universitas matana dapat dinyatakan dengan persamaan regresi $Y=6,656+1,106 X$. Dari persamaan regresi di atas dapat diartikan bahwa, maka nilai rata-rata desain bangunan paramount skyline complex 1,106 setiap nilai pengaruh bertambah 0 , maka nilai rata-rata aksebilitas driver online ke universitas matana adalah regresi $Y=6,656+1,106(0)=6,656$ Misalkan jika nilai setting peron sama dengan 10, maka nilai rata-rata aksebilitas driver online ke universitas matana adalah regresi $Y=6,656+1,106(10)=17,716$ Garis regresi dapat digambarkan berdasarkan persamaan yang telah ditemukan adalah sebagai berikut:

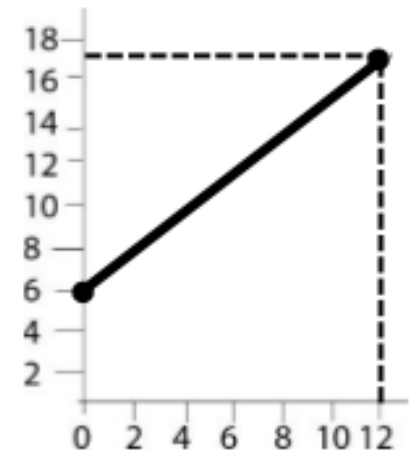

Gambar 5. Persamaan Regresi (Sumber: Analisa, 2018)

\section{Kesimpulan}

Dari rekapitulasi data, maka didapat kesimpulan, bahwa:

1. Kondisi desain bangunan paramount skyline complex tergolong sangat buruk. 
PENGARUH DESAIN BANGUNAN PARAMOUNT SKYLINE COMPLEX TERHADAP AKSESIBILITAS DRIVER ONLINE KE UNIVERSITAS MATANA

2. Aksebilitas driver online ke universitas matana tergolong buruk atau sulit, atau tidak bisa beradaptasi dengan baik.

Dari hasil uji hipotesis diketahui koefisien korelasi dari penelitian ini adalah sebesar 0,776 yang berarti bahwa terdapat hubungan yang positif antara desain bangunan paramount skyline complex terhadap aksebilitas driver online ke universitas matana yang koefisien korelasinya kuat.

Dilihat dari $r$ table bahwa untuk $n=50$ dengan taraf kesalahan sebesar $5 \%$ maka harga $r$ table $=$ 0,238 dan ketentuannya $r$ hitung lebih kecil dari $r$ table ( $r$ hitung $<r$ table) maka Ho diterima dan Ha tidak. Tetapi sebaliknya bila $r$ hitung lebih besar dari $r$ table ( $r$ hitung $>r$ table) maka Ha diterima dan Ho tidak. Ternyata $r$ hitung $(0,776)$ lebih besar dari $r$ table $(0,238)$ dengan demikian terdapat hubungan positif yang kuat antara desain bangunan paramount skyline complex terhadap aksebilitas driver online ke universitas matana.

Hasil perhitungan t hitung sebesar 8,520 dan nilai t table sebesar 1,677. Dengan demikian t hitung . t table, maka Ha diterima dan Ho ditolak, artinya terdapat hubungan yang signifikan antara desain bangunan paramount skyline complex terhadap aksebilitas driver online ke universitas matana. Adapun besar pengaruh desain bangunan paramount skyline complex terhadap aksebilitas driver online ke universitas matana dapat diketahui dari nilai determinasi, dimana setelah dilakukan perhitungan diperoleh koefisien determinasi sebesar 60,2\%. Ini menunjukkan bahwa keberpengaruhan variable $\mathrm{x}$ (desain bangunan paramount skyline complex) terhadap variable $\mathrm{y}$ (aksebilitas driver online ke universitas matana) di universitas matana sebesar 60,2\%, dan sisanya sebesar $39,8 \%$.

Maka sangat direkomendasikan untuk menata kembali aksesbilits sesuai dengan kebutuhan pengguna, seperti: 1 . Peletakan area penjempuan di aera lobby universitas matana 2. Mempertegas area penjemputan yang tersedia sudah cukup untuk memilih mana yang lebih dekat ke uniersitas matana 3. Mengatur pola sirkuasi penjemputan penumpang di area universitas matana

\section{Daftar Pustaka}

Purwanto. (2007). Instrumen Penelitian Sosial dan Pendidikan. Yogyakarta: Pustaka Pelajar.

Sujarweni dan Endrayanto (2012). Statiska Untuk Penelitian. Yogyakarta: Graha IImu.

Pengertian Kampus. https://id.scribd.com/document/339051381/Pengertian-Kampus. Dipostkan pada 2017. Diakses pada 25 november 2018.

Aksesbilitas.https://www.academia.edu/11228695/AKSESIBILITAS_Rizky_Priyatna_?

auto=download . Dipostkan pada 2106. Diakses pada 25 november 2018.

Dipl. Ing Mathias Brockhaus (2012). Neufert Architects Data, Edisi Empat. English: Pustaka Pelajar Sugiono. 2013. Metode Penelitian Kuantitatif, Kualitatif, dan R\&D. Bandung: Alfabeta.

Trihendradi, C. 2013. Langkah Praktis Menguasai Statistik untuk Ilmu Sosial Kesehatan Konsep \& Penerapannya Menggunakan SPSS. Yogyakarta: Andi Offset. 